BIOTROPIA No. 6, 1992/1993: 45-54

\title{
REVIEW OF AQUACULTURE GENETIC RESEARCHES IN THAILAND
}

\author{
UTHAIRATNA-NAKORN \\ Department of Aquaculture, Faculty of Fisheries, Kasetsart University, \\ Bangkok 10903, Thailand
}

Aquaculture business has been well established in Thailand for more than 40 years. The most recent data indicated a total production of 260380 tons. Sixty-five percent of the total production came from coastal aquaculture, mainly tiger prawn (Penaeus monodon) culture. Other important species for coastal aquaculture are banana prawn $(P$. merguensis), cockle (Anadara granosa), green mussel (Perna viridis), oyster (Crassostrea belcheri, Saccostrea commercialis), sea bass (Lates calcarifer) and grouper (Epinephelus tauvina). Freshwater aquaculture, although produced only $35 \%$ of the annual production, provides major protein source for people in rural areas. Important freshwater species are Nile tilapia (Oreochromis niloticus), tawes (Puntius gonionotus), sepat Siam (Trichogasterpectoralis), walking catfish (Glorias spp.), stripped catfish (Pangasius sutchi) and giant freshwater prawn (Macrobrachium rosenbergii).

Optimum aquacultural practises, namely stocking density, nutrition requirement and water quality have been obtained in most cultured species. But genetic approach has not been considered, thus resulting in deterioration in economic traits which might be due to excessive inbreeding (reviewed by Uraiwan 1989) and/or negative selection (Wongsangchan 1985).

The history of researches on genetics in aquaculture in Thailand started in 1982 when the aquaculture genetic programme in form of a network has been established at the National Inland Fisheries Institute, Department of Fisheries. This programme was supported by the International Development Research Centre (IDRC, Canada) in cooperation with Dalhousie University, Canada (Uraiwan 1989). In the same year a genetic improvement programme aiming at improving economic characters of some economic fish species has been conducted at the Department of Aquaculture, Kasetsart University. Paralelly a course in Fish Genetics has been offered. Since then different approaches of genetics have been applied with final objectives on improving aquaculture production of the country. Researches being conducted are reviewed according to the following fish species. 


\section{Nile tilapia (Oreochromis niloticus)}

Nile tilapia was first introduced to Thailand in March, 1965 as a present from the Crown Prince of Japan to His Majesty King Bhumipol (Duangsawasde et al. 1982 cited by Uraiwan 1989). The original stock consisted of 50 pairs of fish. Nowadays, it has been cultured all over the country and ranks the first in annual production in the recent years (Department of Fisheries 1991). In fact, most of the cultured stocks are contaminated by hybridizing with $O$. mossambicus introduced earlier. The only one pure strain is maintained at Chitralada Royal Palace.

Main genetic problems in tilapia culture in Thailand are:

1. Slow growth which might be a result of inbreeding depression caused by the small number of foundation stock. Unintentional negative selection might also be a cause of the slow growth (Wongsaengchan 1985).

2. Unacceptable appearances, namely dark colour and long shape, resemble $O$. mossambicus.

Therefore, genetic improvement programmes have been conducted to solve these problems.

Selection programmes using within family selection have been conducted since 1986 aiming at improving the growth of Nile tilapia. Sixteen families were produced from each of the Chitralada strain and Chitralada x Nakornpathrom cross. The rotation crossing between these families was applied in each generation. After 3 generations of selection the selected lines grew an average of 17 and $13 \%$ faster than those of the control and the station seed production lines, respectively (Uraiwan et al. 1989 and Uraiwan et al. 1982).

Moreover, indirect selection for increasing growth rate has been performed by Uraiwan (1989). In this selection programme offsprings of each of 5 different families were grouped into 3 categories : early maturing (21-23 weeks), medium maturing (25 - 27 weeks) and late maturing (> 27 weeks). Selected fish from the five families were mixed together according to maturing classification. Results revealed that the direct response to selection was significant. The fish selected for early maturing matured 11 to 14 days earlier than those selected for late maturing. The selection indirectly resulted in a genetic growth gain. The early maturing selected line was significantly larger and grew faster than the late maturing selected line (size 19 - 26\% larger and growth 5 - 9\% faster). Phenotypic correlation coefficient between age and size at maturity ranged between 0.3-0.9. There were no differences in prematurity growth rates between the selected and unselected lines (Uraiwan and Virasith 1989). 


\section{Thai red tilapia}

Thai red tilapia is a hybrid of Oreochromis niloticus and O. mossambicus. It has been originally observed at Ubonratchathani Fisheries Station, in north-eastern Thailand (Jarimopas 1988). Selection programme for better growth rate of Thai red tilapia has been conducted since 1982 (Jarimopas 1989). Size-specific selection was used to prevent effects of asynchronous spawning and variation of mouth-brooding duration on size differences among offspring obtained from mass spawning. In each selection generation twenty-five pairs of parents were mass spawned. Fry were collected for a week to obtain approximately 2000 fry. After a rearing period of about 6 weeks fry were graded. Only the medium size group was kept and reared for about 8 more weeks. Selection was performed when the fish were 14 weeks old. After 6 generations of selection, the selected strain of Thai red tilapia was in weight and length $6.76 \%$ and $4.09 \%$ greater $(\mathrm{P}<0.05)$, respectively, compared to control line at 12 weeks of age (Jarimopas and Nukwan 1989). Realized $\mathrm{h}^{2}$ were 0.44 for weight and 0.53 for length. This selection programme is continuing.

\section{Thai walking catfish (Clarias spp)}

There are 3 species of Clarias being cultured in Thailand. C. macrocephalus is the most acceptable due to good meat quality, thus commands high price. Culture of this species faces problems of slow growth and high disease susceptibility.

C. batrachus is an alternative species for farmers who could not cope with the risk. Although its growth and disease resistance is better than $C$. macrocephalus, it is not so acceptable due to poor meat quality, thus its price is very low. Recently, African catfish, $C$. gariepinus has been introduced to Thailand because of its high growth rate. But, again its meat is not acceptable among Thai consumers. Therefore, an attempt was made to combine the advantages of $C$. gariepinus and $C$. macrocephalus by hybridizing these 2 species. Successful cross has been obtained between female $C$. macrocephalus x male $C$. gariepinus but not the reciprocal one (Nukwan et al. 1990). Hybrid has improved growth and disease resistance compared to female parent. Although its meat quality and appearances could not totally replace that of $C$. macrocephalus, nowadays it comprises more than $90 \%$ of Clarias production of the country. This hybrid has been found to be partly fertile. Further studies are going on at the Department of Fisheries in order to study genetic properties of the hybrid for its genetic improvement in the future (Lawanyavudth personal communication). 
In fact, hybridization experiments attempting to solve the problems of $C$. macrocephalus were conducted before. Tarnchalanukit (1986) made crosses between $C$. macrocephalus and Pangasius sutchi which has faster growth rate and more resistance to disease than $C$. macrocephalus. The author reported 4 hybrid morphotypes which were described later to be actually 2 morphotypes found to be diploid and triploid hybrids (Na-Nakorn et al. 1992a). Moreover, the authors also reported gynogenetic offsprings arisen from this cross. Although these hybrids were not useful for aquaculture, they might contribute knowledge on the phylogenic relationship of these 2 species which belong to different classes (Na-Nakorn et al. 1992a).

At present, although problems have been partly solved by culturing of hybrid Clarias, more serious problems emerge which are shortage of female C. macrocephalus brooders. Therefore, genetic improvement programmes of $C$. macrocephalus have been continued.

Jarimopas et al. (1989) conducted mass selection for fast growing $C$. macrocephalus starting in January 1986. After 3 successive selection generations the selected line was $11.8 \%$ heavier and $2.35 \%$ longer than the control line. Selection response in weight and length were $26.21 \mathrm{~g}$ and $0.66 \mathrm{~cm}$, respectively. Realized heritability of weight and length was 0.47 and 0.30 respectively.

Selection programmes for resistance to Aeromonas hydrophila which is the most serious disease were conducted at the Department of Aquaculture, Faculty of Fisheries, Kasetsart University during 1987-1989 (Na-Nakorn et al., 1992b). C. macrocephalus was collected from 5 different localities in Thailand. Their performances including resistance to A. hydrophila were compared but only slight differences were observed. Mass selection was performed in the F2 generation arisen from all possible crosses of the 5 strains. The 104 day-old fish were intraperitoneally injected with A. hydrophila suspension and survivors were kept as selected brooders. After one generation of selection, little improvement was observed in resistance to A. hydrophila. Heritability of liability for this trait was 0.17. Unfortunately the selected fish died of Flexibacter columnaris which always occurred in winter and made a second generation of selection impossible.

During 1987- 1988 a cross breeding experiment was conducted hoping to benefit from heterosis. Semi-diallel crosses were performed using fish collected from the southern and central parts of Thailand. Results showed that progenies of the cross between females from the south and males from the central grew better than the pure-breds and reciprocal cross. Heterosis was shown for body weight and length at the age of 2, 3 and 3.5 months. There were no differences in disease resistance among progenies of different crosses (Na-Nakorn et al. undated). Since this experiment was done in tanks, therefore it is being repeated in earthen ponds which is a normal practise for Clarias culture. 
Chromosome manipulation has been applied to improve growth of $C$. macrocephalus. Triploid fish were induced using cold shock $\left(7^{\circ} \mathrm{C}, 25\right.$ minutes) applied immediately after fertilization. The shock resulted in $80 \%$ triploid fry. Growth comparison showed that triploid fish grew slower than diploid ones. The survival rate of triploids was lower than that of diploids (Na-Nakorn and Lakhaanantakun 1992).

Attempting to combine techniques in biotechnology and quantitative genetics Na-Nakorn et al. (1992d) and Na-Nakorn et al. (1992c) induced gynogenesis in $C$. macrocephalus to produce highly inbred lines for further cross breeding. Meiotic gynogenesis was induced by activation of $C$. macrocephalus eggs using irradiated sperm of Pangasius sutchi. Sperm dilution (1:100 in Ringer's solution) was UV-irradiated (30 $\mathrm{W}, 30 \mathrm{~cm}, 2$ mins). After the activated eggs were subjected to cold shock, best results were achieved at shock temperature between $6-11{ }^{\circ} \mathrm{C}$ with shock duration of 14 minutes and starting 3.5 - 4.5 minutes after activation. Gynogenetic fish were all females. Thus, sex reversal to maleness is needed to produce male parents. Recently, in my laboratory 17 alpha methyltestosterone has been orally administered to feeding fry of $C$. macrocephalus. Results showed that administration of 30 or $60 \mathrm{mg} \mathrm{MT} / \mathrm{kg}$ feed for either 30 or 60 days reduced growth at 60 days of MT treated fish as well as survival rate at 30 days. No changes in sex were observed, except for intersex fish found in both MT treated groups being treated for 60 days. Paradoxical feminization was presumably accounted for the intersex fish. At present five different stocks of gynogenetic $C$. macrocephalus have been produced. Sex reversal experiments are continuing dealing with lower doses of MT being administered to fry of different ages. A different kind of hormone, $11 \mathrm{~B}$ androstenedione is being used.

\section{Thai silver barb or tawes (Puntius gonionotus)}

Being accepted among Thai consumers, tawes produces an average annual production of more than 11000 tons between 1987-1989 (Department of Fisheries 1991).

Inferior growth rate of males has been widely accepted which may be a result of their early maturing (4 months compared to 8 months in females). In normal rearing conditions females reach marketable size (500-700 g) within 8-12 months while males grow to only $300 \mathrm{~g}$ in the same period. Thus, the production of sterile triploids, which could potentially have better growth than diploids at time of sexual maturation, may provide a practical solution to this problem. Na-Nakom and Legrand (1992) induced triploidy in tawes by subjecting fertilized eggs to cold shock $\left(15^{\circ} \mathrm{C}\right)$. They found that cold shock applied immediately after fertilization 
lasting 15 and 30 minutes resulted in 95.45 and $90.45 \%$ triploid fry, respectively, Hatching percentage relative to control was 46.53 and $16.01 \%$ for shock durations if 15 and 30 minutes. Triploid fish were sterile. However, growth of triploids and liploids has not yet been compared due to the small sample size.

All female stock of tawes have been attempted by crossing sex-reversed male genetic female) with normal female as well as by inducing gynogenesis. Sangsri 1991) reported sex-reversed tawes to maleness by oral administration of 17 alpha nethyltestosterone to 1 and 2 weeks old fry. Dosages of MT used were quite high ^30$120 \mathrm{mg} / \mathrm{kg}$ feed) and numbers of sterile gonads were observed in the groups ireated for 30 days. Some sex-reversed testes were histologically observed. Treatment period of 60 days caused high proportion of sterile gonads. Progeny testing of the presumed sex-reversed male is being performed at the Department of Aquaculture.

Stock of tawes with high percentage of females (98.7\%) was produced by Roongratri et al. (1992) using gynogenesis induction techniques. Eggs were activated with $\mathrm{UV}$-irradiated sperm of tawes $11.8 \mathrm{mJcm}^{-2}$ ). At 1.5 minute after activation eggs were subjected to cold shock $\left(2 \pm 0.1^{\circ} \mathrm{C}\right)$ for 10 minutes. A maximum survival rate of $61.3 \%$ of viable diploid gynogenetic offsprings (relative to control) was obtained. The gynogenetic offsprings will be sex-reversed to produce sex-reversed males which will be crossed with normal females to produce inbreeding-free all-female stock.

\section{Crustaceans}

Application of genetics to aquaculture of crustaceans is limited due to lack of techniques in broodstock rearing of most species such as Penaeus monodon. However, population genetics of $P$. monodon in the Gulf of Thailand and the Andaman Sea was studied (Sodsuk et al. 1992). This may provide useful information for genetic improvement programmes in the near future.

In giant freshwater prawn (Macrobrachium rosenbergii) which has been successfully cultured in Central Thailand, the genetic aspect of this species has recently been a matter of concern. Meewan et al. (1992) estimated the heritability of carapace length of this species and reported $h^{2}$-value of $0.04 \pm 0.22,0.13 \pm 0.07$ and $0.26 \pm 0.11$ based on paternal, maternal and fullsib analyses, respectively. This study provided useful information for further selection programmes for fast growing stock, provided that carapace length and growth are positively correlated. 


\section{Mollusks}

Culture of marine mollusks in Thailand is solely based on naturally produced seeds. Hatchery seed production is limited at laboratory scale, thus limited genetic study of these species. However, genetic improvement of oyster has been carried out at the Department of Marine Science, Chulalongkorn University (Jarayabhand and Jindalikit 1992) attempting to produce a triploid small oyster, Saccostrea cucullata. Thermal shocks $\left(4^{\circ} \mathrm{C}\right.$ and $\left.35^{\circ} \mathrm{C}\right)$ were applied to fertilized eggs 20 minutes after fertilization. Results showed that shock duration of 6 minutes for cold shock and 6 or 15 minutes for heat shock gave an average $40 \%$ of triploids. Growth and other economic important characters were not investigated.

\section{Basic researches relevant to aquaculture}

Cytogenetic researches especially karyotype studies of various fish species were conducted (Tabel 1). Unfortunately the application of the results was not discussed in most of the reports.

Biochemical genetic studies have been conducted in Clarias spp. Serum protein of $C$. batrachus and $C$. macrocephalus was analysed using SDS-polyacrylamide gel electrophoresis. The electrophoresis patterns were found to be species-and sex-specific (Jondeung and Na-Nakorn 1986). Lawanyawut et al. (1992) conducted allozyme

Table 1. Chromosome number of some fishes of Thailand

\begin{tabular}{lcl}
\hline \multicolumn{1}{c}{ Species } & Chromosome no. (2n) & \multicolumn{1}{c}{ References } \\
& & \\
\hline Osteochilus hasselti & 46 & Magtoon et al. (1988) \\
Puntius daruphani & 50 & Magtoon et al. (1988) \\
Pangasius larnaudii & 60 & Magtoon and Donsakul (1988) \\
$P$. sutchi & 60 & Na-Nakon and Donsakul (1988) \\
P. gonionotus & 50 & Donsakul and Magtoon (1989) \\
Clarias macrocephalus & 54 & Donsakul and Magtoon (1989) \\
C. batrachus & 100 & Donsakul and Magtoon (1990) \\
Notopterus chitala & 42 & Donsakul and Magtoon (1990) \\
N. blanci & 42 & Donsakul and Magtoon (1990) \\
N. notopterus & 42 & Donsakul and Magtoon (1991) \\
Channa striata & 44 & Donsakul and Magtoon (1991) \\
C. micropeltes & 44 & Donsakul and Magtoon (1991) \\
C. lucius & 48 & Donsakul and Magtoon (1991) \\
C. gachua & 112 &
\end{tabular}


studies in $C$. gariepinus, C. macrocephalus and their hybrids. Sixteen protein loci were resolved. Three loci, PGI-2, LDH-1 and MDH-2, showed fixed differences between the parent species while the hybrids patterns were always heterozygotes. For gene transferring the growth hormone gene of the giant freshwater catfish (Pangasianodon gigas), the world biggest catfish, has been sequenced, and cloned at the Department of Biochemistry, Mahidol University (Panyim personal communication). The gene has been transferred to bacteria and expression was observed. Successful cloning of this gene encourages scientists to transfer the gene to economic fish species.

\section{Future studies}

During the past 10 years aquaculture genetics was applied to only a few of completely domesticated species. Genetic research and genetic improvement programmes are urgently needed to solve different problems occurring in different species, for example slow growth in sand goby (Oxyeleotris marmoratus), inferior growth and less acceptability of male sepat Siam, deterioration of growth of freshwater prawn, etc.

Intensive studies must be conducted in order to solve problems which cause a bottle neck in breeding and propagation of some economic species such as the problem of broodstock rearing in $P$. monodon or artificial breeding of snakehead (Channa striata) etc. Without these techniques genetic improvement of those species is impossible.

Genetic conservation of natural stocks must be emphasized. Genetic stocks of wild fish are being destroyed due to intentional stocking of hatchery stock to natural water as well as unintentional escaping of hatchery stocks. Genetic diversity is affected and hence, particular gene pool useful for genetic improvement programmes may be destroyed.

In order to prevent undesirable genetic change, effects of introduction of new species in natural water have to be studied in the field before introduction.

\section{REFERENCES}

Department of Fisheries. 1991. Fisheries Statistics of Thailand 1989. Fisheries Statistics Sub-Division, Tech. Pap. No. 5/1991. Dept. of Fisheries, Bangkok. 92 p.

DONSAKUL, T. and W. MAGTOON. 1989. A chromosome study of walking catfish, Claries batrachus and C. macrocephalus in Thailand. In: Proceedings of the 27th Kasetsart University Conference: 426-428. Kasetsart University, Bangkok. (In Thai). 
DONSAKUL, T. and W. MAGTOON. 1990. A chromosome study on three species of featherbacks, Notop-terus chilata (Hamilton), N. bland D'Aubenton and N. notopterus (Pallas), from Thailand. In: Proceedings of the 28th Kasetsart University Conference, 29 - 31 January 1990:459 - 466. Kasetsart University, Bangkok. (In Thai).

DONSAKUL, T. and W. MAGTOON. 1991. A. chromosome study on five species channid fishes (Channa, Family Channidae), from Thailand. In: Proceedings of the 29th Kasetsart University Conference, 4-7 February, 1991: 561-574. Kasetsart University, Bangkok. (In Thai).

JARAYABHAND, P. and J. JNDALIKIT. 1992. Chromosome manipulation in small oyster, Saccostrea cucullata, by thermal shock : Evidences from trochophore larvae (abstract). Abstract of the International Workshop on Genetics in Aquaculture and Fisheries Management, 31 st August - 4th September 1992. ASEAN-EEC Aquaculture Development and Coordination Programme. University of Stirling, Scotland.

JARIMOPAS, P. 1988. Thai red tilapia. Thai Fisheries Gazette. 41 (1): 41 -43.

JARIMOPAS, P. 1989. Realized response of Thai red tilapia to 6 generations of size-specific selection for growth. In: Final Report, Fish Genetics Project (Phase II) : $147-164$. Submitted to the International Development Research Centre. National Aquaculture Genetics Institute, Department of Fisheries, Bangkok.

JARIMOPAS, P., A. KUMNAN and J. WONGCHAN. 1989. Mass selection of Clarias macrocephalus Gunther for growth (3 generations). In: Final Report, Fish Genetics Project (Phase II): 177 - 191. Submitted to the International Development Research Centre. National Aquaculture Genetics Institute, Department of Fisheries, Bangkok.

JARIMOPAS, P. and S. NUKWAN. 1989. Evaluation on growth rate of selected strain Thai red tilapia. In: Final Report, Fish Genetics Project (Phase II) : 165- 176. Submitted to the International Development Research Centre. National Aquaculture Genetics Institute, Department of Fisheries, Bangkok.

JONDEUNG, A. and U. NA-NAKORN. 1986. Analysis of serum proteins of Clarias batrachus (Linnaeus) and $C$. macrocephalus (Gunther) by electrophoresis. The Kasetsart J. (Nat. Sci.) 20 (1): 108 - 111.

MAGTOON, W. and T. DONSAKUL. 1988. Karyotypes of Pangasiid catfishes, Pangasius larnaudii and P. sutchi. In: Proceedings of the 26th Kasetsart University Conference, 3-5 February, 1988 : 239 - 244. Kasetsart University, Bangkok. (In Thai).

MAGTOON, M., U. TIPSAENAand Y. TAKI. 1988. Karyotypes of cyprinid fishes, Osteochilus hasseltii and Puntius daruphani. In: Proceedings of the 26th Kasetsart University Conference, 3 - 5 February, 1988 : 235-238. Kasetsart University, Bangkok. (In Thai).

MEEWAN,M., C.K. LN,S. TUMWASORN and R.W. DOYLE. 1992. Growth heritability of giant freshwater prawn (abstract). In: Abstracts of the Third Asian Fisheries Forum, October 26-30, 1992, Singapore: 81.

NA-NAKORN, U. and A. LEKHAANANTAKUN. 1992. The effects of triploidy on survival, growth and feed conversion ratio of Clarias macrocephalus. Manuscript submitted to Symposium on Fish Genetics and Its Application to Aquaculture and Fishery Management, 8-10 December 1992, Bogor, Indonesia.

NA-NAKORN, U. and E. LEGRAND. 1992. Induction of triploidy in Puntius gonionotus (Sleeker). Fishery Research Bulletin No. 18. Kasetsart University, Bangkok. 10 p.

NA-NAKORN,U., P. SIDTHIKRAIWONG, W. TARNCHALANUKIT and T.R. ROBERT. 1992a. Chromosome study of hybrid and gynogenetic offspring of artificial crosses between members of the catfish families Clariidae and Pangasiidae. Manuscript submitted to Environmental Biology of Fishes. 
NA-NAKORN,U., S. CHANTSAWANG and W. TARNCHALANUKIT. 1992b. Response to mass selection for disease resistance in Clarias macrocephalus. Manuscript submitted to Journal of Applied Aquaculture.

NA-NAKORN,U., W. LUANGPROMPORN and R.A. DUNHAM. 1992d. Induction of gynogenesis in Clarias macrocephalus eggs using irradiated sperm of Pangasius sutchi and cold shock. Paper presented in the Third Asian Fisheries Forum, October 26 - 30, 1992, Singapore.

NA-NAKORN, U., W. RANGSIN and S. WITCHASUNKUL. 1992c. Suitable conditions for induction of gynogenesis in Clarias macrocephalus using sperm of Pangasius sutchi. Paper presented in International Workshop on Genetics in Aquaculture and Fisheries Management, 31st August $-4^{\text {th }}$ September 1992, University of Stirling, Scotland.

NA-NAKORN, U., W. TARNCHALANUKIT and C. LMSUWAN: undated. Genetic Improvement of Walking Catfish (Clarias macrocephalus Gunther) for Bacterial Disease Resistance. Report submitted to the National Research Council of Thailand. 163 p. (In Thai).

NUKWAN, S., M. tangtrongPairo, K. LaWANYAWUT and P. VEeRASIDTH. 1990. Cross breeding between Clarias macrocephalus and Clarias gariepinus. In: Proceedings of the 28th Kasetsart University Conference, 29-31 January, 1990: 553-567. Kasetsart University, Bangkok.

ROONGRATRI, N., D.J. PENMAN and T. VIPUTHANUMART. 1992. Induction of diploid gynogenesis in Java carp, Puntius gonionotus (Bleeker). (abstract) In: Abstracts of the Third Asian Fisheries Forum. October 26-30, 1992. Singapore : 83 .

SANOSRI, J. 1991. Effects of methyltestosterone on sex reversal of Puntius gonionotus. Master Thesis, Kasetsart University. Bangkok. 79 p. (In Thai).

SODSUK, S., B.J. MCANDREW and D.J. PENMAN. 1992. Genetic population structure of the giant tiger prawn (Penaeus monodon Fabricus, 1978) in the Gulf of Thailand and the Andaman Sea. (Abstract). Abstracts of the International Workshop on Genetics in Aquaculture and Fisheries Management, 31 August-4 September, 1992. ASEAN-EEC Aquaculture Development and

Coordination Programme, University of Stirling, Scotland.

TARNCHALANUKIT, W. 1986. Experimental hybridization between catfishes of the families Clariidae and Pangasiidae in Thailand. Env. Biol. of Fishes 16(4) : 317-320.

URAIWAN, S. 1989. Aquaculture genetics improvement programs appropriate for Thailand and other developing countries in Asia. In: Final Report, Fish Genetics Project (Phase II): 279-384. Submitted to the International Development Research Centre. National Aquaculture Genetics Institute, Department of Fisheries, Bangkok.

URAIWAN, S., M. MEEWANand A. KUMNANE. 1989. Within-family selection for increasing growth rate of Oreochromis niloticus (Linn.). In: Final Report, Fish Genetics Project (Phase II): 26-36. Submitted to the International Development Research Centre. National Aquaculture Genetics Institute, Department of Fisheries, Bangkok.

URAIWAN, S. and P. VIRASITH. 1989. Selection in Thai Oreochromis niloticus (Linn.) by line performance growth test, (abstract) In: Abstracts of the Third Asian Fisheries Forum, October 26-30, 1992, Singapore : 81.

URAIWAN, S., R.W. DOYLE and M. MEEWAN. 1992. Evaluation of response to within-family selection of Oreochromes niloticus (Linn.) by line performance growth test, (abstract) In: Abstracts of the Third Asian Fisheries Forum, October 26-30, 1992, Singapore: 81.

WONGSANGCHAN, A. 1985. Broodstock selection and management study. Technical paper in Fish Genetic (Thailand) Project. National Inland Fisheries Institute, Department of Fisheries, Bangkok. 36 p. 